\title{
Agriculture and natural resources business owners' economic and communication concerns early in the COVID-19 pandemic
}

\author{
L. Baker ${ }^{1}$, M. Kandzer², S. Rampold ${ }^{3}$, C. Chiarelli ${ }^{4}$, H. Peterson ${ }^{5}$, A. McLeod-Morin ${ }^{6}$
}

\section{Abstract}

The purpose of this study was to describe agriculture and natural resource (ANR) leader business owners' initial concerns and feelings about the impacts of the 2019 novel coronavirus (COVID-19) pandemic. Based on the theories of opinion leadership and bounded rationality, researchers analyzed survey findings to identify and describe ANR business owners' (a) business and economic concerns associated with COVID-19, (b) communication concerns associated with COVID-19, and (c) any other concerns or impacts experienced due to COVID-19. Findings indicated that the majority of respondents were concerned about their bottom lines, employees missing work, and their abilities to provide employees a safe workplace. Additionally, respondents were concerned about the impact of COVID-19 on the U.S. economy. Regarding communication concerns, respondents were concerned about others sharing inaccurate COVID-19 information. When asked about additional concerns related to COVID-19, many respondents noted their concerns about economic impacts, personal and business finances, and canceled events causing them to become unable to interact with customers. Overall, the biggest concerns were related to economic impacts and misinformation.

Recommendations for future research are to continue to assess this population as the pandemic continues, and again when the health crisis ends to understand the recovery process for ANR leader business owners.

\section{Keywords}

Bounded rationality, opinion leadership, survey

1. Lauri M. Baker, Associate Professor, University of Florida, 1408 Sabal Palm Drive, Level 2, PO Box 110126, Gainesville, FL 32611, lauri.m.baker@ufl.edu, https://orcid.org/0000-0002-4241-6077

2. Michaela Kandzer, graduate student, University of Florida, 1408 Sabal Palm Drive, Level 2, PO Box 110126, Gainesville, FL 32611, michaelashaw@ufl.edu, https://orcid.org/0000-0002-7488-4246

3. Shelli D. Rampold, research coordinator, Center for Public Issues Education in Agriculture and Natural Resources, University of Florida, 1408 Sabal Palm Drive, Level 2, PO Box 110126, Gainesville, FL 32611, srampold@ufl.edu, https://orcid.org/0000-0003-4815-7157

4. Christy C. Chiarelli, assistant extension scientist, University of Florida, 121-B Bryant Hall, PO Box 112060, Gainesville, FL 32611, ccw@ufl.edu, https://orcid.org/0000-0002-4839-5932

5. Hikaru Hanawa Peterson, professor, University of Minnesota, 1194 Buford Ave, St. Paul, MN 55108, hhp@umn.edu, http://orcid.org/0000-0001-5190-0015

6. Ashley McLeod-Morin, communications coordinator, University of Florida, 1408 Sabal Palm Drive, Level 2, PO Box 110126, Gainesville, FL 32611, ashleynmcleod@ufl.edu, https://orcid.org/0000-0002-8649-9783 


\section{Introduction and Problem Statement}

The 2019 novel coronavirus (COVID-19) emerged in late 2019 as an infectious disease caused by a novel strand of the coronavirus (World Health Organization [WHO], 2020). COVID-19 was first announced by WHO on January 9, 2020 (The American Journal of Managed Care Staff [AMJC], 2020). The United States (US) had its first confirmed case on January 21, 2020 and declared a national emergency in early March. By March 20, 2020, many states had enacted stay-at-home orders, which shut down businesses, economies, and made nearly 10 million Americans jobless (Taylor, 2020). By May 28, 2020, the US had surpassed a total of 100,000 COVID-19 related deaths.

The impacts of COVID-19 were significant across the agricultural industry (Duvall, 2020). While the demand for farm labor remained unchanged, the availability of skilled workers was reduced due to factors such as school closures and childcare needs, sick workers, and uncertainty surrounding the H-2A migrant worker program (Beatty et al., 2020). Process changes also occurred as drastic declines in restaurant dining required farmers to redirect products from restaurants to retailers or market directly to consumers. Communication issues surrounding lack of effective broadband among prominent farm communities in rural areas were also exacerbated as people relied on the internet for economic opportunities, informational updates, and telehealth (Nelson, 2020).

State-level agriculture and natural resources (ANR) leadership programs were established to increase rural leadership (Miller, 1976). Today there are 42 state ANR leadership programs that seek to help leaders gain new perspectives on local, regional, and global issues (Waldrum, n.d.). The present study is focused on the felt concerns of ANR business owner leaders during the early stages of the COVID-19 pandemic to help identify how to support these leaders throughout and following the era of COVID-19.

\section{Theoretical and Conceptual Framework}

In an effort to understand the economic impacts of COVID-19 on the ANR industry early in the pandemic, two theoretical frameworks guided this study: opinion leadership and bounded rationality. Together, these frameworks offer insight into ANR leaders' perceptions and opinions on the economic impacts of COVID-19. Lazarsfeld et al. (1948) first named opinion leaders in 1948. Over time, other scholars have added to the original framework of opinion leaders to define opinion leaders as those who are (a) more involved in activities relating to their specialty area; (b) more informed about innovations because of more media exposure related to their specialty area; (c) having similar demographics as non-leaders with the exception of a higher socio-economic status (Corey, 1971; Rogers, 2003); and (d) more active in speaking, volunteering, and engaging in events and discussions within their community (Weimann, 1994). Opinion leaders can be identified through a variety of ways, including selfidentification, staff selection, or the position they hold in their organization (Valente \& Pumpuang, 2007). Within ANR, alumni of ANR leadership development programs are 
considered opinion leaders within their communities and can forecast trends for their communities (Chiarelli et al., 2009; Lamm et al., 2014; Lamm \& Lamm, 2019).

The theory of bounded rationality (Simon, 1957) accounted for an individual's cognitive limitations, information imperfection, and time constraints in the decision-making process, departing from the idea that humans are generally rational (Simon, 1997). Cognitive limitations refer to the mental limits of humans to process the infinite amount of information available (Gigerenzer \& Selton, 2001), but opinion leaders can serve as those who read and interpret multiple media for people around them (Corey, 1971; Rogers, 2003). Information imperfection occurs whenever an individual is unable to possess, recall, and understand all available information. Time constraints occur whenever individuals must operate within a specified deadline to make a decision (Gigerenzer \& Selton, 2001). In addition to his idea of bounded rationality, Simon $(1957 ; 1977)$ coined the term satisficing. Satisficing is the strategy of weighing all available options of choice until an option is chosen that either meets or exceeds a predetermined threshold of satisfaction (Gigerenzer \& Selton, 2001; Wheeler, 2020). Satisficing can occur during a time of crisis when a decision is needed quickly and is a result of bounded rationality.

\section{Purpose}

The purpose of this study was to describe concerns and perceived impacts of the COVID-19 pandemic at its onset among business-owning ANR leaders. The lens of opinion leadership helped define the population of interest for the study purpose. The theory of bounded rationality guided the development of the purpose and shaped the study objectives for a focus on understanding the economic impacts and communication concerns that may have bound ANR business owners' decision making during the early stage of the COVID-19 pandemic. Three objectives specific to ANR leader business owners guided this study:

1. Describe business and economic concerns associated with COVID-19.

2. Describe communication concerns associated with COVID-19.

3. Identify other concerns and impacts of COVID-19.

\section{Methods}

Data were collected from March 16 to April 21, 2020 using an online survey distributed via listserv by program directors for ANR leadership programs. The International Association of Programs for Agricultural Leadership (IAPAL) served as the initial recruitment organization. Leadership program directors who agreed to participate sent an initial announcement of the upcoming study, an invitation to participate that included informed consent and the link to the online survey, and three follow-up reminder emails. The lack of direct contact between researchers and the population of this study may have posed limitations to the effectiveness of the data collection efforts. 


\section{Sample and Target Population}

The targeted population for this study was active listserv members of U.S. ANR leadership programs who were business owners. Eight of the 40 U.S. leadership programs agreed to participate, including Arizona Project CENTRL, LEAD Delaware, California Agricultural Leadership Foundation, Wedgworth Leadership Institute, Leadership Idaho Agriculture, Indiana Agricultural Leadership Program, LEAD New York, and Palmetto Leadership for the Environment, Agriculture and Forestry (LEAF). From 3,172 individuals contacted, 225 useable responses were obtained for a $14.9 \%$ response rate. The focus of this paper is on a subsample of the ANR leaders who identified as business owners $(n=125)$.

\section{Instrument}

An original, researcher-designed questionnaire served as the instrument. It was reviewed for face and content validity by a panel that consisted of the director, faculty, and staff members at the University of Florida One Health Center of Excellence who have expertise in research pertaining to infectious diseases and public health initiatives and by faculty in agricultural economics at two large land-grant universities. The instrument was reviewed by the panel for content accuracy, clarity of wording, readability, and survey flow (Colton \& Covert, 2007).

Three sections of the questionnaire were used to meet the objectives of this study: (a) business and economic concerns; (b) communication concerns; and (c) other concerns and impacts. To assess objectives one and two, respondents were first asked to indicate if they had specific concerns related to COVID-19 impacts on economic and communication concerns $(1=$ yes; 2 = no). Respondents who reported having concern for an item were then asked to indicate how concerned they were about this item on a 5-point ordinal scale from $1=$ only slightly concerned to $5=$ extremely concerned. To assess objective three, an open-ended question was asked: What other concerns and impacts have you experienced from COVID-19?

\section{Data Analysis}

For objectives one and two, data were analyzed using the SPSS26 software package. Analyses consisted of descriptive statistics (e.g., means, standard deviations, frequencies, and percentages). To address objective three, open-ended responses of other concerns and impacts of COVID-19 experienced by ANR business owners were collected. Data were analyzed using Glaser's constant comparative method (Glaser, 1965) to identify emerging themes. The researchers then grouped emerging themes according to the frequency of response.

\section{Findings}

Respondents were primarily white $(f=110,88.0 \%)$, male $(f=77,61.6 \%)$, and ranged from 25 to 74 years old. More respondents fell within the income ranges of $\$ 75,000$ to $\$ 149,999(f=42$, $33.6 \%)$ and $\$ 150,000$ to $\$ 249,999(f=30,24.0 \%)$ than any other bracket, and most respondents held a 4-year college degree or higher level of education $(f=106,84.8 \%)$. Further, respondents represented 10 states, 8 leadership organizations, and more than 14 sectors of the ANR industry (see Table 1). 


\section{Table 1}

Demographic Characteristics of Respondents $(N=125)$

\begin{tabular}{|c|c|c|}
\hline Variable & $f$ & $\%$ \\
\hline \multicolumn{3}{|l|}{ Sex } \\
\hline Male & 77 & 61.6 \\
\hline Female & 48 & 38.4 \\
\hline \multicolumn{3}{|l|}{ Age Category ${ }^{a}$} \\
\hline 20 to 29 & 9 & 7.2 \\
\hline 30 to 39 & 30 & 24.0 \\
\hline 40 to 49 & 27 & 21.6 \\
\hline 50 to 59 & 26 & 20.8 \\
\hline 60 to 69 & 27 & 21.6 \\
\hline 70 to 79 & 4 & 3.2 \\
\hline \multicolumn{3}{|l|}{ Race $^{b}$} \\
\hline White & 110 & 88.0 \\
\hline Asian or Pacific Islander & 1 & 0.8 \\
\hline Hispanic & 6 & 4.8 \\
\hline Other & 5 & 4.0 \\
\hline \multicolumn{3}{|l|}{ Income ${ }^{c}$} \\
\hline$\$ 24,999$ or less & 1 & 0.8 \\
\hline$\$ 25,000$ to $\$ 49,999$ & 5 & 4.0 \\
\hline$\$ 50,000$ to $\$ 74,999$ & 19 & 15.2 \\
\hline$\$ 75,000$ to $\$ 149,999$ & 42 & 33.6 \\
\hline$\$ 150,000$ to $\$ 249,999$ & 30 & 24.0 \\
\hline$\$ 250,000$ or more & 23 & 18.4 \\
\hline \multicolumn{3}{|l|}{ Education ${ }^{d}$} \\
\hline High school graduate (includes GED) or less than $12^{\text {th }}$ grade & 0 & 0.0 \\
\hline Some college, no degree & 9 & 7.2 \\
\hline 2-year college degree (Associates, Technical, etc.) & 9 & 7.2 \\
\hline 4-year college degree (Bachelor's, etc.) & 74 & 59.2 \\
\hline Graduate or professional degree & 32 & 25.6 \\
\hline \multicolumn{3}{|l|}{ Leadership Organization Affiliation } \\
\hline Arizona Project CENTRL, The Center for Rural Leadership & 4 & 3.2 \\
\hline California Agricultural Leadership Foundation & 19 & 15.2 \\
\hline LEAD Delaware & 5 & 4.0 \\
\hline Wedgworth Leadership Institute & 35 & 28.0 \\
\hline Leadership Idaho Agriculture & 6 & 4.8 \\
\hline Indiana Agricultural Leadership Program & 1 & 0.8 \\
\hline LEAD New York & 50 & 40.0 \\
\hline $\begin{array}{l}\text { Palmetto Leadership for the Environment, Agriculture and } \\
\text { Forestry (LEAF) }\end{array}$ & 6 & 4.8 \\
\hline
\end{tabular}




\begin{tabular}{|c|c|c|}
\hline Arizona & 6 & 4.8 \\
\hline California & 19 & 15.2 \\
\hline Delaware & 5 & 4.0 \\
\hline Florida & 32 & 25.6 \\
\hline Idaho & 6 & 4.8 \\
\hline Indiana & 1 & 0.8 \\
\hline Montana & 1 & 0.8 \\
\hline New York & 50 & 40.0 \\
\hline North Carolina & 1 & 0.8 \\
\hline South Carolina & 4 & 3.2 \\
\hline \multicolumn{3}{|l|}{ Type of Residence } \\
\hline A farm in a rural area & 60 & 48.0 \\
\hline Rural area, not a farm & 29 & 23.2 \\
\hline Subdivision in a town or city & 13 & 10.4 \\
\hline Urban or suburban area outside of the city limits & 19 & 15.2 \\
\hline \multicolumn{2}{|l|}{ Industry Sector } & 3.2 \\
\hline Agricultural communication (e.g., writing, public relations, etc.) & 5 & 4.0 \\
\hline Agricultural direct-to-consumer sales & 7 & 5.6 \\
\hline Agricultural finance & 2 & 1.6 \\
\hline Agricultural processors (e.g., citrus processing, milling, etc.) & 6 & 4.8 \\
\hline Agricultural services (e.g., irrigation, insurance, etc.) & 11 & 8.8 \\
\hline Animal agriculture & 23 & 18.4 \\
\hline Forestry production (e.g., timber production) & 4 & 3.2 \\
\hline Fruit, vegetable, and specialty crop production & 27 & 21.6 \\
\hline Landscape & 2 & 1.6 \\
\hline $\begin{array}{l}\text { Membership-based industries/services (e.g., Farm Bureau, } \\
\text { Grower associations, etc.) }\end{array}$ & 6 & 4.8 \\
\hline Nursery growers & 7 & 5.6 \\
\hline Public and/or government agency & 3 & 2.4 \\
\hline Row crop production & 13 & 10.4 \\
\hline Other & 9 & 7.2 \\
\hline Industry Sector & 5 & 4.0 \\
\hline Agricultural communication (e.g., writing, public relations, etc.) & 7 & 5.6 \\
\hline Agricultural direct-to-consumer sales & 2 & 1.6 \\
\hline Agricultural finance & 6 & 4.8 \\
\hline Agricultural processors (e.g., citrus processing, milling, etc.) & 11 & 8.8 \\
\hline Agricultural services (e.g., irrigation, insurance, etc.) & 23 & 18.4 \\
\hline Animal agriculture & 4 & 3.2 \\
\hline Forestry production (e.g., timber production) & 27 & 21.6 \\
\hline Fruit, vegetable, and specialty crop production & 2 & 1.6 \\
\hline Landscape & 6 & 4.8 \\
\hline \multicolumn{3}{|l|}{ Number of Employees } \\
\hline None & 8 & 6.4 \\
\hline
\end{tabular}




\begin{tabular}{lll} 
Less than 10 & 44 & 35.2 \\
10 to 19 & 16 & 12.8 \\
20 to 49 & 22 & 17.6 \\
50 to 99 & 10 & 8.0 \\
100 to 249 & 10 & $8 . .0$ \\
250 to 499 & 9 & 7.2 \\
500 to 999 & 1 & 0.8 \\
1,000 or more & 1 & 0.8 \\
\hline
\end{tabular}

${ }^{a}$ Responses missing from 2 participants

${ }^{\mathrm{b}}$ Responses missing from 3 participants

${ }^{\mathrm{c}}$ Responses missing from 5 participants

${ }^{\mathrm{d}}$ Responses missing from 1 participant

e Responses missing from 4 participants

\section{Objective One: Business and Economic Concerns}

Regarding business- and economic-related concerns associated with COVID-19, the majority of respondents were concerned about the impacts of COVID-19 on their bottom line $(f=113$, $90.4 \%)$, about employees missing work $(f=84,67.2 \%)$, and their ability to provide a safe workplace for employees $(f=72,56.6 \%$; see Table 2$)$.

\section{Table 2}

ANR Leader Business Owners' Business Concerns Associated with COVID-19

\begin{tabular}{|c|c|c|c|c|}
\hline Concern & Yes & & No & \\
\hline & $f$ & $\%$ & $f$ & $\%$ \\
\hline $\begin{array}{l}\text { I am concerned about the impacts of COVID-19 } \\
\text { on my bottom line. }\end{array}$ & 113 & 90.4 & 12 & 9.6 \\
\hline $\begin{array}{l}\text { I am concerned about my employees missing } \\
\text { work because of COVID- } 19 \text {. }\end{array}$ & 84 & 67.2 & 41 & 32.8 \\
\hline $\begin{array}{l}\text { I am concerned about my ability to provide a } \\
\text { safe workplace for my employees because of } \\
\text { COVID-19. }\end{array}$ & 72 & 57.6 & 53 & 42.4 \\
\hline $\begin{array}{l}\text { I am concerned about my ability to provide a } \\
\text { safe environment for my customers/clients } \\
\text { because of COVID-19. }\end{array}$ & 62 & 49.6 & 63 & 50.4 \\
\hline $\begin{array}{l}\text { I am concerned about the impacts of COVID-19 } \\
\text { on people's willingness to travel to visit my } \\
\text { business or natural resource location. }\end{array}$ & 54 & 43.2 & 71 & 56.8 \\
\hline
\end{tabular}

Respondents who indicated concern about an item were then asked to rate how concerned they were about that item on a 5-point scale. Table 3 lists the items in the order of average scores $(M)$ in a descending order. Respondents were relatively more concerned about impacts of COVID-19 on their bottom line $(M=4.38, S D=.78)$ and their ability to provide a safe workplace for their employees $(M=4.27, S D=.79)$ than other business-related items. 


\section{Table 3}

Degree of Concern for Business-Related Items

\begin{tabular}{llll}
\hline Business Concern Item & $M$ & $S D$ & $n$ \\
\hline $\begin{array}{l}\text { I am concerned about the impacts of COVID-19 on my } \\
\text { bottom line. }\end{array}$ & 4.38 & .78 & 113 \\
$\begin{array}{l}\text { I am concerned about my ability to provide a safe } \\
\begin{array}{l}\text { workplace for my employees because of COVID-19. } \\
\text { I am concerned about impacts of COVID-19 on people's }\end{array}\end{array}$ & 4.27 & .79 & 72 \\
$\begin{array}{l}\text { willingness to travel to visit my business or natural } \\
\text { resource location. }\end{array}$ & & 58 \\
$\begin{array}{l}\text { I am concerned about my ability to provide a safe } \\
\text { environment for my customers/clients because of } \\
\text { COVID-19. }\end{array}$ & 4.08 & .87 & 62 \\
$\begin{array}{l}\text { I am concerned about my employees missing work } \\
\text { because of COVID-19. }\end{array}$ & 4.04 & .98 & 83 \\
\hline
\end{tabular}

The majority of ANR leader business owners were concerned about all economic-related concern items, with the most expressing concerns for the impact of COVID-19 on the U.S. economy $(f=123,98.4 \%)$ and the fewest for increased cost of food due to COVID-19 $(f=58$, 46.4\%; see Table 4).

\section{Table 4}

ANR Leader Business Owners' Economic Concerns

\begin{tabular}{lllll}
\hline Economic Concern Item & Yes & \multicolumn{3}{l}{ No } \\
\hline \begin{tabular}{l} 
I am concerned about the impact of COVID-19 on the U.S. \\
\cline { 2 - 5 } economy
\end{tabular} & 123 & 98.4 & 2 & 1.6 \\
$\begin{array}{l}\text { I am concerned about the impact of COVID-19 on my } \\
\text { state's economy. }\end{array}$ & 122 & 97.6 & 3 & 2.4 \\
$\begin{array}{l}\text { I am concerned about the impact of COVID-19 on the } \\
\text { global economy. }\end{array}$ & 119 & 95.2 & 6 & 4.8 \\
$\begin{array}{l}\text { I am concerned about potential labor shortages in } \\
\text { agriculture and natural resources sectors due to COVID- }\end{array}$ & 112 & 89.6 & 13 & 10.4 \\
$\begin{array}{l}\text { l9. } \\
\text { I am concerned about the financial impact of COVID-19 on } \\
\text { me personally. }\end{array}$ & 107 & 85.6 & 18 & 14.4 \\
$\begin{array}{l}\text { I am concerned about an increased cost of food because } \\
\text { of COVID-19. }\end{array}$ & 58 & 46.4 & 67 & 53.6
\end{tabular}

Table 5 summarizes the follow-up ranking of concerns, which mirrored the number of respondents indicating these as concerns. Compared to the other economic-related items, respondents indicated the most concern for the impacts of COVID-19 on the U.S. economy $(M=$ 
$4.62, S D=.68)$ and the lowest degree of concern for the increased cost of food $(M=3.86, S D=$ 1.03; see Table 5).

\section{Table 5}

Degree of Concern for Economy-Related Items

\begin{tabular}{llll}
\hline Item & $M$ & $S D$ & $n$ \\
\hline $\begin{array}{l}\text { I am concerned about the impact of COVID-19 on the } \\
\text { U.S. economy }\end{array}$ & 4.62 & .68 & 123 \\
I am concerned about the impact of COVID-19 on my & 4.42 & .73 & 121 \\
$\begin{array}{l}\text { state's economy. } \\
\text { I am concerned about potential labor shortages in } \\
\text { agriculture and natural resources sectors due to COVID- }\end{array}$ & 4.41 & .78 & 112 \\
$\begin{array}{l}\text { I9. } \\
\text { I am concerned about the impact of COVID-19 on the } \\
\text { global economy. }\end{array}$ & 4.33 & .81 & 119 \\
$\begin{array}{l}\text { I am concerned about the financial impact of COVID-19 } \\
\text { on me personally. }\end{array}$ & 4.14 & .98 & 107 \\
I am concerned about an increased cost of food & 3.86 & 1.03 & 58 \\
because of COVID-19. & & & \\
\hline
\end{tabular}

\section{Objective Two: Communication Concerns}

The majority of business owner ANR leaders were concerned with all communication items (see Table 6) with the largest number being concerned about members of the public sharing inaccurate information about COVID-19 $(f=108,86.4 \%)$ and the smallest number being concerned about not personally getting accurate information related to COVID-19 $(f=70,56 \%)$.

\section{Table 6}

ANR Leader Business Owners' Communication Concerns Associated with COVID-19

\begin{tabular}{lllll}
\hline Communication Concern Item & \multicolumn{3}{l}{ Yes } & \multicolumn{3}{l}{ No } \\
\hline & 108 & 86.4 & 17 & 13.6 \\
I am concerned members of the public are sharing & & & & \\
$\begin{array}{l}\text { inaccurate information about COVID-19. } \\
\text { I am concerned media and news outlets are sharing }\end{array}$ & 99 & 79.2 & 26 & 20.8 \\
$\begin{array}{l}\text { inaccurate information about COVID-19. } \\
\text { I am concerned members of the general public are not } \\
\text { getting accurate information about COVID-19. }\end{array}$ & 98 & 78.4 & 27 & 21.6 \\
$\begin{array}{l}\text { I am concerned agricultural/farm laborers are not getting } \\
\text { accurate information about COVID-19. }\end{array}$ & 82 & 65.6 & 43 & 34.4 \\
$\begin{array}{l}\text { I am concerned my loved ones are not getting accurate } \\
\text { information about COVID-19. }\end{array}$ & 76 & 60.8 & 49 & 39.2 \\
$\begin{array}{l}\text { I am concerned I am not getting accurate information } \\
\text { about COVID-19. }\end{array}$ & 70 & 56.0 & 55 & 44.0
\end{tabular}


Similar to the economic-related concerns, the rankings of communication concerns mirrored the number of respondents expressing them (see Table 7). ANR leader business owners indicated the most concern for members of the public sharing inaccurate information related to COVID-19 $(M=4.06, S D=1.00)$ and the lowest degree of concern for not getting accurate information themselves $(M=3.73, S D=1.20)$.

\section{Table 7}

Degree of Concern for Communication-Related Items

\begin{tabular}{llll}
\hline Item & $M$ & $S D$ & $n$ \\
\hline $\begin{array}{l}\text { I am concerned members of the public are sharing } \\
\text { inaccurate information about COVID-19. }\end{array}$ & 4.06 & 1.00 & 108 \\
$\begin{array}{l}\text { I am concerned members of the general public are not } \\
\text { getting accurate information about COVID-19. }\end{array}$ & 4.01 & 0.96 & 98 \\
$\begin{array}{l}\text { I am concerned media and news outlets are sharing } \\
\text { inaccurate information about COVID-19. }\end{array}$ & 3.93 & 1.08 & 99 \\
$\begin{array}{l}\text { I am concerned agricultural/farm laborers are not getting } \\
\text { accurate information about COVID-19. }\end{array}$ & 3.88 & 1.36 & 82 \\
$\begin{array}{l}\text { I am concerned my loved ones are not getting accurate } \\
\text { information about COVID-19. }\end{array}$ & 3.82 & 1.12 & 76 \\
$\begin{array}{l}\text { I am concerned I am not getting accurate information } \\
\text { about COVID-19. }\end{array}$ & 3.73 & 1.20 & 70
\end{tabular}

\section{Objective 3: Other Concerns and Impacts Experienced by ANR Business Owners}

Respondents were asked to answer an open-ended question asking what other concerns and impacts of COVID-19 they had experienced as ANR business owners $(f=119)$. Responses to this question were analyzed to identify key emerging themes (see Table 8). The top four themes that emerged were a form of concern for economic impact with the top being economic impact $(f=42)$ followed by concern for personal and business finances $(f=19)$, concerns for cancelled events and being unable to interact with customers $(f=13)$, concerns for shutdowns and being unable to move products $(f=11)$, and concerns for not having access to workers and employees $(f=11)$. Economic impact was defined as general concern for economics. This could be general statements made by respondents that related directly to the economy, pricing, supply, and demand, or loosely related to finances. Concern for personal/business finances was directly related to finances and being unable to make ends meet. Shutdowns/unable to move product was specifically related to being unable to conduct business due to forced shutdowns related to COVID-19, which was particularly relevant at the time of data collection as this was when people were starting to quarantine, and non-essential businesses were not allowed to operate in some states. Some of the least frequently occurring themes were concern for working remotely $(f=1)$, work related travel $(f=1)$, and personal sanity $(f=1)$. Full results are in Table 8 . 


\section{Table 8}

Other Concerns and Impacts of COVID-19 Experienced by ANR Business Owners $(f=119)$

\begin{tabular}{|c|c|c|}
\hline Response Category & Examples of Answers & $f(\%)$ \\
\hline Economic impact & $\begin{array}{l}\text { Businesses have to close, financial impact, long } \\
\text { term economic impact, commodity prices, } \\
\text { economic health, consumer confidence, decrease } \\
\text { in demand, unable to engage in commerce, } \\
\text { economic recovery, marker erosion, supply chain } \\
\text { disruptions, trade restrictions, long term impacts, } \\
\text { small business impact, local economy impacts }\end{array}$ & $42(35.3)$ \\
\hline $\begin{array}{l}\text { Concern for } \\
\text { person/business } \\
\text { finances }\end{array}$ & $\begin{array}{l}\text { Maintaining admin functions, cattle and dairy } \\
\text { market decline, customers unable to purchase } \\
\text { products, fewer transactions than normal, } \\
\text { financial instability, loss of income, effect to } \\
\text { bottom line, lack of demand for products }\end{array}$ & 19 (16.0) \\
\hline $\begin{array}{l}\text { Canceled } \\
\text { events/unable to } \\
\text { interact with } \\
\text { customers }\end{array}$ & $\begin{array}{l}\text { Canceled professional development events, } \\
\text { unable to interact with stakeholders, reliance on } \\
\text { face to face relationships, expenses associated } \\
\text { with canceled events, customers not coming to } \\
\text { business }\end{array}$ & 13 (11.0) \\
\hline $\begin{array}{l}\text { Shutdowns/unable } \\
\text { to move products }\end{array}$ & $\begin{array}{l}\text { Milk processing plants shutdown, products not } \\
\text { reaching market, forestry work being shutdown, } \\
\text { resource availability }\end{array}$ & $11(9.2)$ \\
\hline $\begin{array}{l}\text { Worker/employee } \\
\text { availability }\end{array}$ & $\begin{array}{l}\text { Availability of harvest personnel, ability to get } \\
\text { H2A workers, employees unable to work when } \\
\text { sick }\end{array}$ & $11(9.2)$ \\
\hline $\begin{array}{l}\text { Health and safety of } \\
\text { workforce }\end{array}$ & $\begin{array}{l}\text { Not enough cleaning/protection materials } \\
\text { available, customers not cooperating and causing } \\
\text { unsafe workplace, employee's financial situations, } \\
\text { employee stress level, employees feeling scared }\end{array}$ & $10(8.4)$ \\
\hline Concern for others & $\begin{array}{l}\text { Senior students missing out on graduation, older } \\
\text { family members, people not taking it seriously, } \\
\text { people utilizing domestic food supply, } \\
\text { phycological effect on children, children not being } \\
\text { able to go to school, people without insurance, } \\
\text { overall health and wellbeing of farmers }\end{array}$ & $10(8.4)$ \\
\hline Shortages & $\begin{array}{l}\text { Shortages in grocery stores, overall food } \\
\text { shortages, shortages of household items }\end{array}$ & $2(1.7)$ \\
\hline
\end{tabular}




\begin{tabular}{|c|c|c|}
\hline Response Category & Examples of Answers & $f(\%)$ \\
\hline Health insurance & $\begin{array}{l}\text { Increased price of health insurance, no access to } \\
\text { health insurance }\end{array}$ & $2(1.7)$ \\
\hline $\begin{array}{l}\text { Improper actions } \\
\text { politically }\end{array}$ & $\begin{array}{l}\text { Nonessential workers need to be compensated, } \\
\text { inaccurate information }\end{array}$ & $2(1.7)$ \\
\hline Policy responses & $\begin{array}{l}\text { Policy is switching its focus from agriculture, } \\
\text { policy is flourishing }\end{array}$ & $2(1.7)$ \\
\hline Working remotely & Working remotely, ability to keep projects going & $1(0.8)$ \\
\hline Traveling for job & $\begin{array}{l}\text { Patronage to hotels and restaurants due to forced } \\
\text { work travel }\end{array}$ & $1(0.8)$ \\
\hline Personal sanity & My sanity & $1(0.8)$ \\
\hline
\end{tabular}

\section{Conclusions, Discussion, and Recommendations}

ANR leader business owners who participated in this study expressed high levels of concern about COVID-19 impacts related to business, economics, and information and communication. The greatest business-related concern felt by respondents was the impacts of COVID-19 on their business bottom line. They were less concerned about things within their control, e.g., providing a safe workplace and safe environment for customers. The primary economic-related concerns were those beyond ANR leader business owners' own operation. Respondents were more concerned about the impacts of COVID-19 on the state, national, and global economies than their personal financial situations. Labor shortages and increased food costs were also of concern among respondents, but to a relatively lower degree than other economic-related items. Regarding communication-related issues, respondents were comparatively most concerned about the public sharing inaccurate information. They were least concerned about personally getting inaccurate information, which may be due to the tendency for opinion leaders to be informed persons who serve as interpreters of information around them (Corey, 1971; Rogers, 2003; Weimann, 1994). However, it should be noted that more than half of respondents indicated being concerned they are not receiving accurate information.

The results of the present work indicate ANR leader business owners may indeed be bound by available information when making business decisions in the early stages of the pandemic. When this study was conducted, March 16 to April 21, 2020, much was still unknown about COVID-19, and information was changing daily. Such an environment made the theory of bounded rationality especially applicable to this research at the time when this study was conducted, especially considering the new and unique challenges ANR business owners faced when making decisions during uncertain times (Gigerenzer \& Selton, 2001). While these business owners have had more time to assess how their decisions at the onset of the pandemic have fared (Gigerenzer \& Selton, 2001; Wheeler, 2020), larger picture concerns are 
expected to remain prevalent until a clear medical breakthrough is announced. More specific concerns, such as employees missing work because of COVID-19, have likely fluctuated in accordance with the rate of new cases in the communities. It is recommended that this study be conducted later in the pandemic. Additionally, future research should be conducted to understand the recovery process for ANR leader business owners when the COVID-19 health crisis has passed.

\section{Programming Recommendations}

ANR leadership programs should include programming based on factors seemingly outside of opinion leaders' control. One recommendation is to continue providing or begin providing programming related to the development of a crisis communication plan. Even though this study focused on a fairly short time frame, an initial disruption to business activities had changed the economic landscape for many business owners. This type of significant disruption to business activities is a reminder of the value of having a crisis communication plan in place prior to a business disruption or other crisis. ANR leadership programs should ensure each participant, especially business owners, are adept at crisis planning. While programs may be limited in their curriculum offerings due to program time constraints, if participants lose their businesses due to an inability to manage a crisis, then the remainder of the leadership skills they learn are less meaningful. Through equipping business owners with crisis communication plans, concerns related to securing supply chain issues, ensuring consumer confidence, and planning for economic impacts may be mitigated. Further, considering the critical role of opinion leaders in implementing community-based health efforts (Valente et al., 2007), developing train-the-trainer programs for ANR leader business owners may be beneficial in equipping other business owners in the ANR sector with the information and skills needed to mitigate the impacts of COVID-19.

ANR leadership programs should be overt in teaching program participants about their influence as opinion leaders. ANR business leaders' highest levels of communication-related concerns involved members of the public not sharing or receiving accurate information. According to opinion leadership theory, ANR business leaders are important links in the information channel distribution chain and can serve as an effective vehicle for communication between their surrounding communities and ANR leadership agencies (Valente et al., 2007).

Agricultural leadership programs could also act as a hub of reliable information during widespread crisis by connecting information from various agricultural opinion leaders into one online repository. As individual industries receive information from unique sources, having a hub of cross-industry information would be a value-added resource for participants and alumni of leadership programs.

\section{Limitations}

It should be noted that this study is limited to one point in time, March 16 to April 21, 2020. It is also limited by a low response rate, likely due to the population dealing with the impacts of COVID-19 during the data collection period. A large majority of responses came from three out 
of 40 U.S. state ANR leadership programs. The sampling method was also limited by a lack of direct access to the population by study researchers.

\section{Acknowledgements}

This work was supported by the UF/IFAS Center for Public Issues Education in Agriculture and Natural Resources (PIE Center), https://piecenter.com.

\section{References}

Beatty, T., Hill, A., Martin, P. L., \& Rutledge, Z. (2020). Covid-19 and farm workers: Challenges facing California agriculture. ARE Update, 23(5), 2-4. https://s.giannini.ucop.edu/uploads/giannini_public/91/cc/91cc19a8-21b2-45bf-a7d2f4e17e8009c4/v23n5.pdf

Center for Disease Control and Prevention. (2020). What you should know about COVID-19 to protect yourself and others. https://www.cdc.gov/coronavirus/2019-ncov/preventgetting-sick/prevention.html

Chiarelli, C., Stedman, N., Carter, H., \& Telg, R. (2010). The impact of organizational source and credibility and the factors that contribute to opinion leaders' decisions to diffuse information. Journal of Southern Agricultural Education Research, 60(1), 104Type equation here.117. http://jsaer.org/pdf/vol60Whole.pdf\#page=107

Colton, D., \& Covert, R. (2007). Designing and constructing instruments for social research and evaluation. Jossey-Bass.

Corey, L. G. (1971). People who claim to be opinion leaders: Identifying their characteristics by self-report. Journal of Marketing, 35(4), 48-53. https://doi.org/10.1177/002224297103500409

Duvall, Z. (2020). Impact of COVID-19 on agriculture: Lessons from COVID-19. American Farm Bureau Federation. https://www.fb.org/viewpoints/lessons-from-covid-19

Gigerenzer, G., \& Selton, R. (2001). Bounded rationality: The adaptive toolbox. MIT Press.

Glaser, B. (1965). The constant comparative method of qualitative analysis. Social Problems, 12(4), 436-445. https://doi.org/10.2307/798843

Lamm, K. W., \& Lamm, A. J. (2019). A multi-level evaluation of the relationship between leadership program satisfaction, opinion leadership, and intent to participate in an alumni program. Journal of Leadership Education, 18(4), 40-46. https://doi.org/10.12806/V18/14/R4 
Lamm, K. W., Lamm, A. J., \& Carter, H. S. (2012). Opinion leadership development: Context and audience characteristics count. Journal of Agricultural Education, 55(2), 91-105. https://https://doi.org/10.5032/jae.2014.02091

Lazarsfeld, P., Berelson, B., \& Gaudet, H. (1948). The people's choice (2nd ed.). Columbia University Press.

Miller, H. L. (1976). The Kellogg farmers' study program: An experience in rural leadership development. The W. K. Kellogg Foundation. https://www.canr.msu.edu/afre/uploads/files/Hepp/Kellogg Farmers Study Program Final Report 1976 v2.pdf

Nelson, M. (2020). Keeping rural communities connected while socially distanced. American Farm Bureau Federation. https://www.fb.org/market-intel/keeping-rural-communitiesconnected-while-socially-distanced

Rogers, E. M. (2003). Diffusion of innovations (5th ed.). Free Press.

Simon, H. A. (1957). Models of man: Social and rational. John Wiley \& Sons, Inc.

Simon, H. A. (1997). Models of bounded rationality: Empirically grounded economic reason (3rd ed.). MIT Press.

Taylor, D. B. (2020). How the coronavirus pandemic unfolded: A timeline. New York Times. https://www.nytimes.com/article/coronavirus-timeline.html

The American Journal of Managed Care Staff. (2020, July 3). A timeline of COVID-19 developments in 2020. The American Journal of Managed Care. https://www.ajmc.com/view/a-timeline-of-covid19-developments-in-2020

Valente, T. W., \& Pumpuang, P. (2007). Identifying opinion leaders to promote behavior change. Health Education \& Behavior, 34(6), 881-896. http://doi.org/10.1177/1090198106297855

Waldrum, J. (n.d.). IAPAL directory. KARL Legendary Rural Leaders. Retrieved September 8, 2020, from http://karlprogram.com/about-us/iapal-directory/

Weimann, G. (1994). The influentials: People who influence people. State University of New York Press.

Wheeler, G. (2020). Bounded Rationality. In The Stanford Encyclopedia of Philosophy (Spring 2020 Edition). https://plato.stanford.edu/archives/spr2020/entries/boundedrationality/ 
World Health Organization. (2020). Coronavirus. https://www.who.int/healthtopics/coronavirus\#tab=tab 1

(C) 2020 by authors. This article is an open access article distributed under the terms and conditions of the Creative Commons Attribution license (http://creativecommons.org/licenses/by/4.0/). 